\title{
Proceeding
}

11th World Congress of Performance Analysis of Sport, 16-18 November 2016. International Society of Performance Analysis of Sport. Alicante, Spain

\section{How does it affect the setter intervention to the block participation, in high level male volleyball?}

\author{
JARA GONZALEZ-SILVA , CARMEN FERNÁNDEZ-ECHEVERRIA, FERNANDO CLAVER, MANUEL \\ CONEJERO,M. PERLA MORENO
}

Faculty of Sport Sciences, University of Extremadura, Spain

\begin{abstract}
The aim of the study was to determine how different variables of the setting action affect to the block participation in high level male volleyball. The study sample was comprised of a total of 2742 game actions, divided into 1371 setting actions and 1371 block actions, corresponding to the observation of the 24 matches of the third stage of the World Male Volleyball Championship, absolute category. The dependent variable was block participation (zero or one blocker, two blockers, three blockers). The independent variables were: setting zone (excellent, acceptable, unacceptable), type of set (standing set, jump set), setting technique (overhand set, forearm set), set's area (zone one, zone two, zone three, zone four, zone six) and tempo of set (first tempo, second tempo, third tempo). The result of this study showed that the variables setting zone, type of set, set's area and tempo of set, were predictors of the block participation. Thus, the decision-making of the setter in the setting action as well as the type, area and tempo of set, has high relevance in game, affecting to the block participation of the opposing team. Key words: SETTING, VOLLEYBALL, MULTINOMIAL LOGISTIC REGRESSION.
\end{abstract}

\section{Cite this article as:}

González-Silva, J., Fernández-Echeverría, C., Claver, F., Conejero, M., \& Moreno, M.P. (2017). How does it affect the setter intervention to the block participation, in high level male volleyball? Journal of Human Sport and Exercise, 12(3proc), S821-S830. doi:https://doi.org/10.14198/jhse.2017.12.Proc3.06

\footnotetext{
Corresponding author. Facultad de Ciencias del Deporte, Universidad de Extremadura, Avenida de la Universidad s/n, 10003, Cáceres, Spain E-mail: gonzálezsilvajara@gmail.com 11th World Congress of Performance Analysis of Sport, 16-18 November 2016. International Society of Performance Analysis of Sport. Alicante, Spain. JOURNAL OF HUMAN SPORT \& EXERCISE ISSN 1988-5202

(c) Faculty of Education. University of Alicante doi:10.14198/jhse.2017.12.Proc3.06
} 


\section{INTRODUCTION}

The match analysis has had a very important role in the performance improvement in different sports ( $O^{\prime}$ Donoghue and Holmes, 2015). Research on match analysis, despite of its amount (Valladares et al., 2016; Valadés et al., 2016), requires to follow deep in over different technical and tactical variables that affect performance (João et al., 2010).

An important game action in volleyball is the set (Matias and Greco, 2011). This action is performed by a specialized player, the setter. This player is responsible of the offensive organization of the team (Castro and Mesquita, 2008), deciding, among other aspects, the setting zone, the tempo of the set (Palao and Manzanares, 2013), as well as its type (standing or jumping). These decisions will be determined by the area from where the set is made (Marcelino et al., 2014), since if the zone is excellent the chances of performing a fast game will increase, whereas if the zone is acceptable or not acceptable it will be reduced (Afonso et al., 2010).

One of the main purposes of the setter is to leave the attacker in the best conditions to attack, taking into account to the opponent team. That is, to live the attacker in front of the minor number of blockers (Moreno et al., 2008).

The block is the first line of defence that team has to counteract the opponents' attack, as well as being a way to get the point directly (Mesquita and César, 2007). In male volleyball, the block action differentiates the level of the teams (Palao et al., 2004).

Blockers, at the time of blocking, can wait for the action of the opponent setter to perform their movement (read-and-react) or anticipate the action of the setter, based on the knowledge of the probabilities of the situation (commit strategy) (Selinger and Ackermann-Blount, 1986). In addition, to achieve a successful block, several key points must be taken into account: the speed of movement and the jumping ability (Lobietti, 2009).

The block can be collective or individual. The number of blockers can range from one to three players, forming single, double or triple blocks. These formations may depend on the speed of the attack, the attack zone (Afonso et al., 2005b), and the tactical and technical variability of the opponent setter (Mesquita et al., 2002).

These three aspects, attack velocity, attack zone and technical and tactical variability of the setter, have a dependence relationship to each other because the velocity and diversity of the setting action is conditioned by the setter ability (Mesquita and Graça, 2002). In addition, through them, the setter tries to create uncertainty in the opponent team and to increase the defence deficit of time (Fröhner and Zimmermann, 1996, Palao et al., 2005).

In the current literature few researches are focused on the study of the relationship between the setting action and the block (Buscá and Febrer, 2012). The majority of the studies analyses, in isolation, the setting or the block actions (Araújo et al., 2009; González-Silva et al., 2016) or study the relationship between the attack and the block actions (Afonso et al., 2005b; Mesquita and César, 2007).

Thus, the aim of the study are to determine how different variables of the set affect to the block participation in high level male volleyball. 


\section{MATERIAL AND METHODS}

\section{Participants}

The study sample was comprised of a total of 2742 game actions, divided into 1371 setting actions and 1371 block actions, corresponding to the observation of the 24 matches (87 sets) of the World Male Volleyball Championship, absolute category. Matches from the third stage were chosen in order to ensure the high level of the teams. The selected sample represented the top twelve national teams in the world. Four matches of each one were observed.

\section{Measures}

The dependent variable considered in our study was the block participation, defined as the number of players that form the block. An adaptation of the criteria suggested in previous investigations (Castro and Mesquita, 2010a; Araújo et al., 2009) has been used, grouping them into the following categories: zero or one blockers, no or one player take part in the block action; two blockers, two players take part in the block action, three blockers, three players take part in the block action.

The independent variables considered in our study were:

Setting zone (Figure 1), defined as the place on the court from where the setting pass was carried out. The categories were: excellent zone/area $A$ (an $10 \mathrm{~m}^{2}$ area, $2 \mathrm{~m}$ long by $5 \mathrm{~m}$ wide, located $1 \mathrm{~m}$ from the right sideline and $3 \mathrm{~m}$ from the left sideline); an acceptable zone/ area B (a $6 \mathrm{~m}^{2}$ area, $2 \mathrm{~m}$ deep from zone 1 , and $3 \mathrm{~m}$ wide, located $2 \mathrm{~m}$ from the right sideline and $4 \mathrm{~m}$ from the left sideline); an unacceptable zone/area $\mathrm{C}$ (which was the equivalent to the game area excluded in the two cases mentioned above), as stablished by Castro and Mesquita (2010).

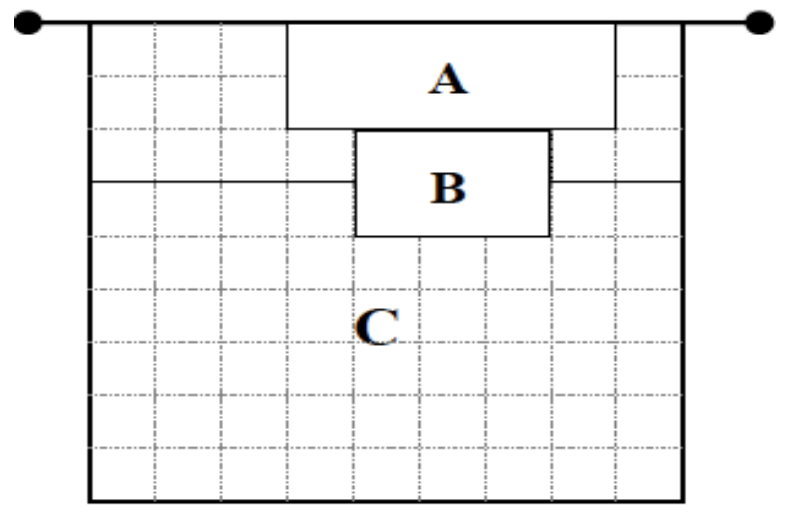

Figure 1. Setting zone (Castro and Mesquita, 2010)

Type of set, defined as the setting carried out by the setters and depending if their feets stay in touch with the floor or not, when the setting action take place. The categories were: a jump set and a standing set (Palao and Martínez, 2013; Palao and Ahrabi-Fard, 2014).

Setting technique, defined as the complete gesture used in the setting pass. The categories were: forearm set and overhand set.

Set's area (Figure 2), defined as the area of the court where the attack takes place. This variable has been considered in previous investigations (Papadimitriou et al., 2004; Tsivika and Papadopoulou, 2008). In our 
study the following categories are differentiated: zone 1 (zone of three meters of width by six meters of length located in the right side in the back part of the field); zone 2 (area three meters wide by three meters long, located at the front of the field, on the upper right side of the net, at the front of the field); zone three, area three meters wide by three meters long located, in the front of the field, in the central area of the net, in the front of the field); zone 4 (area three meters wide by three meters long located, at the front of the field, on the upper left side of the net, at the front of the field); and zone 6 (zone three meters wide by six meters long located in the central part of the back part of the field).

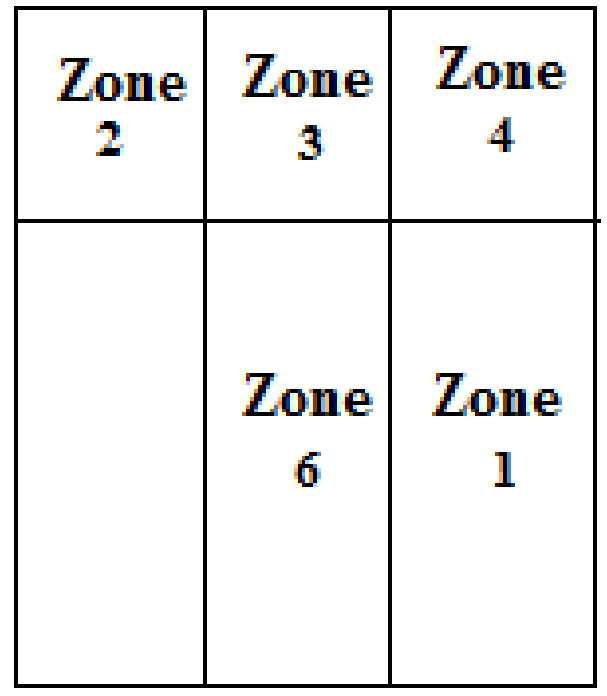

Figure 2. Set's area

Tempo of set, defined as the interaction between the moment when the setter makes contact with the ball and the start of the attacker approach. This variable has been considered in previous investigations (Afonso et al., 2010; Selinger and Ackermann-Blount, 1986). In our study the following categories has been considered: first tempo, the hitter jumped before or when the set was done; second tempo, the hitter was taking the last step of the approach when the set was done; third tempo, the hitter had not started the approach when the set was done.

\section{Procedures and data analysis}

Matches were recorded from above the court, with a perfect view of the entire court, without changing position or cuts during recording, avoiding errors in the procedure. The observational design used was a follow-up, multidimensional and nomothetic design (Anguera et al., 2000). Once the datae were collected, the matches were analysed with the software of observational analysis applied to volleyball VA-Sports, 1.0.75 (Morante, 2014).

\section{Statistical analysis}

An inferential analysis was performed to verify the associations between each one of the variables studied and the block participation. This analysis is presented through the contingency tables, including Chi-Square and Cramer's V values. The statistical significance level considered was $p<.05$. Finally, using the multinomial logistic regression model, the predictions of the dependent variable were obtained, respect to each one of the independent variables. 


\section{RESULTS}

\section{Inferential analysis}

Through the inferential analysis are shown the relationships obtained between each one of the independent variables and the dependent variables, indicating Chi-square and Cramer's V values.

Table 1. Relationships between independent variables and the dependent variable.

\begin{tabular}{llll}
\hline Variables & Sig. & $X^{2}$ & V de Cramer \\
\hline Zona de colocación & .000 & 347.998 & .358 \\
Tipo de colocación & .000 & 102.023 & .274 \\
Zona de envío de la colocación & .000 & 208.560 & .275 \\
Tiempo de colocación & .000 & 343.779 & .353 \\
\hline
\end{tabular}

The variables that were included in the model were the setting zone, type of the set, set's area and tempo of the set because the significant association between the dependent variable and the independent variables.

\section{Predictive analysis}

Results from the multinomial logistic regression analysis are shown in Table 2.

Carrying out the setting action from the acceptable or unacceptable zonea, instead of from the excellent zone, increased the frequency of a block with two blockers (OR=.2.292 y OR=.3.963, respectively), or a block with three blockers (OR=3.455 y OR=43.313, respectively), instead of a block with zero or one blockers.

Carrying out a jumping set, instead of the standing set, reduce the frequency of a triple block $(\mathrm{OR}=.315)$, instead of a block with zero or one blockers.

Carrying out the setting action to zone 4 , instead of the zone 4 , reduce the frequency $(O R=.439)$ of a block with two blockers, instead of a block with zero or one blockers.

Carrying out the setting action to zones 1 or 2, instead of the zone 4 , reduce the frequency $(\mathrm{OR}=.349 \mathrm{y}$ $\mathrm{OR}=.268$, respectively) of a block with three blockers, instead of a block with zero or one blockers.

Carrying out a setting at first and second tempo, instead of the third tempo, reduce the frequency of a block with two blockers ( $\mathrm{OR}=.162$ y $\mathrm{OR}=.464$, respectively) or a block with three blockers $(\mathrm{OR}=.050$ y $\mathrm{OR}=.013$, respectively), instead of a block with zero or one blockers. 
Tabla 2. Modelo predictivo de la participación en bloqueo

\begin{tabular}{|c|c|c|c|c|c|c|c|c|c|}
\hline Variables & $\begin{array}{c}\text { Zero or one } \\
\text { blockers } \\
\%{ }^{a}\end{array}$ & $\begin{array}{c}\text { Two } \\
\text { blockers } \\
\% \\
\end{array}$ & $\begin{array}{l}\text { OR } \\
\text { Crude }\end{array}$ & $\begin{array}{c}\text { OR } \\
\text { Ajusted }\end{array}$ & $p$ & $\begin{array}{c}\text { Three } \\
\text { blockers } \\
\% \\
\end{array}$ & $\begin{array}{l}\text { OR } \\
\text { Crude }\end{array}$ & $\begin{array}{c}\text { OR } \\
\text { Ajusted }\end{array}$ & $p$ \\
\hline \multicolumn{10}{|c|}{ Setting zone } \\
\hline $\begin{array}{l}\text { Acceptable } \\
\text { zone }\end{array}$ & 32.4 & 64.4 & $\begin{array}{c}2.723 \\
(2.126-3.486)^{c}\end{array}$ & $\begin{array}{r}2.292 \\
(1.748- \\
3.005)^{c}\end{array}$ & .000 & 3.2 & $\begin{array}{c}5.186 \\
(2.093- \\
12.850)\end{array}$ & $\begin{array}{c}3.455 \\
(1.294- \\
9.225)^{c}\end{array}$ & .013 \\
\hline $\begin{array}{l}\text { No aceptable } \\
\text { zone }\end{array}$ & 9.7 & 61.2 & $\begin{array}{c}8.655 \\
(5.373-13.942)\end{array}$ & $\begin{array}{c}3.966 \\
(2.380- \\
6.598)^{c}\end{array}$ & .000 & 29.1 & $\begin{array}{l}155.571 \\
(63.884- \\
378.853)\end{array}$ & $\begin{array}{c}43.313 \\
(15.274- \\
122.830)\end{array}$ & .000 \\
\hline Excellent zone $^{b}$ & . & . & . & $\cdot$ & . & . & . & . & . \\
\hline \multicolumn{10}{|c|}{ Type of set } \\
\hline Jump set & 42.2 & 53.2 & $\begin{array}{c}.362 \\
(.198-.663)^{c}\end{array}$ & $\begin{array}{c}.980 \\
(.499- \\
1.923)^{c}\end{array}$ & .952 & 4.8 & $\begin{array}{c}.057 \\
(.029-.115)^{c}\end{array}$ & $\begin{array}{c}.315 \\
(.134-.739)^{c}\end{array}$ & .008 \\
\hline Standing set ${ }^{b}$ & . & . & . & . & . & . & . & . & . \\
\hline \multicolumn{10}{|c|}{ Set's area } \\
\hline Zone one & 22.7 & 70.5 & $\begin{array}{c}1.909 \\
(1.285-2.836) \mathrm{c}\end{array}$ & $\begin{array}{c}1.058 \\
(.681-1.644)^{c}\end{array}$ & .802 & 6.8 & $\begin{array}{c}1.050 \\
(.518-2.127)^{c}\end{array}$ & $\begin{array}{c}.349 \\
(.153-.793)^{c}\end{array}$ & .012 \\
\hline Zone two & 30.6 & 66.3 & $\begin{array}{c}1.333 \\
(.971-1.831)\end{array}$ & $\begin{array}{l}1.022 \\
(.721- \\
1.447)\end{array}$ & .904 & 3.1 & $\begin{array}{c}.354 \\
(.162-.775)\end{array}$ & $\begin{array}{c}.268 \\
(.110-.650)\end{array}$ & .004 \\
\hline Zone three & 76.4 & 23.2 & $\begin{array}{c}.187 \\
(.133-.263)\end{array}$ & $\begin{array}{l}.703 \\
(.424- \\
1.164)\end{array}$ & .170 & .4 & $\begin{array}{c}.019 \\
(.003-.136)\end{array}$ & $\begin{array}{c}.449 \\
(.033-6.108)\end{array}$ & .548 \\
\hline Zone six & 59.1 & 31.8 & $\begin{array}{c}.332 \\
(.203-.542)\end{array}$ & $\begin{array}{c}.439 \\
(.261-.739)\end{array}$ & .002 & 9.1 & $\begin{array}{c}.538 \\
(.242-1.196)\end{array}$ & $\begin{array}{c}43.929 \\
(5.001-385.878)\end{array}$ & .878 \\
\hline Zone four ${ }^{b}$ & & . & $\cdot$ & . & . & . & . & $\cdot$ & . \\
\hline \multicolumn{10}{|c|}{ Tempo of set } \\
\hline $1^{0}$ tempo & 73.4 & 26.1 & $\begin{array}{c}.085 \\
(.060-.118)^{c}\end{array}$ & $\begin{array}{c}.162 \\
(.098-.267)^{c}\end{array}$ & .000 & .6 & $\begin{array}{c}.008 \\
(.002-.034)^{c}\end{array}$ & $\begin{array}{c}.050 \\
(.007-.342)^{c}\end{array}$ & .002 \\
\hline $2^{0}$ tempo & 44.6 & 54.0 & $\begin{array}{c}.288 \\
(.214-.387)\end{array}$ & $\begin{array}{c}.646 \\
(.332-.650)\end{array}$ & .000 & 1.4 & $\begin{array}{c}.033 \\
(.015-.074)\end{array}$ & $\begin{array}{c}.013 \\
(.002-.100)\end{array}$ & .000 \\
\hline $3^{\circ}$ tempo ${ }^{b}$ & $\cdot$ & . & . & . & . & . & . & $\cdot$ & . \\
\hline
\end{tabular}

"a" Category of references for the dependent variable.

"b" Category of reference of the independent variable.

"c" Numbers in brackets refer to the $95 \%$ confidence interval.

\section{DISCUSSION AND CONCLUSIONS}

The aim of the study was to determine how different variables of the set affect to the block participation in high level male volleyball.

The setting zone was as a predictor of block participation, obtaining that when the set was made from acceptable or unacceptable zones, instead of an excellent zone, increased the number of players that participated in the he block.

Moraes et al. (2007), found that setting actions from excelent zones were associated with a blocker or nonformed blocks, and setting from non-ideal zones, faced attackers to two or three blockers. Results that are in line with those obtained in our research.

Setting zone is closely related to the speed of the game, as shown by Afonso et al. (2010), in a high level study. They found that in setting actions from acceptable or unacceptable zones, the options of slow play 
increased, been performed quick actions when the setter performed from an excellent zone. In addition, fast times favours the formation of blocks with fewer players (Afonso et al., 2005a). Therefore, the sets from nonideal zones promotes slow sets which, in turn, lead to an increase in the number of blockers that jump to the block, as shown in our results.

In relation to the type of set, the results showed that this variable is a predictor of the block participation, obtaining that when the setter performed a jumping set instead of a standing set, there was a decrease in the number of opponents that participate in the block.

In line with our results, previous studies found that on those actions, when the setter was jumping, the attacker faced to fewer opponent players in block (Palao and Martínez, 2013).

The deceiving of the rival team is one of the objectives that the setter must achieve. For this, he must set taking into account both his attackers and the opponent (Mesquita and Graca, 2002). An effective weapon to achieve this deception is the jumping set. Through it, the setter tries to reduce the opponents pre-indexes (Hernández, et al., 2003, 2004) and to accelerate the team's game (Buscá and Febrer, 2012). These aspects favour a smaller number of players in the block (Afonso et al., 2005a).

The set's area was shown to be a predictor of the block participation, obtaining that when the setter sent the ball to zone 6 , zone 1 or zone 2 , instead of zone 4 , there was a decrease of number of opponents jumping to the block.

Previous studies did not show results in line with those of our research, since when the set was performed to zone 2 and zone 2, the most frequent were double or triple blocks (Castro and Mesquita, 2008; Afonso et al., 2005a).

The set's area is one of the decisions that the setter make when carrying out the offensive organization of the attack (Palao and Martínez, 2013). For this, to make a good decision, the setter must take into account the characteristics of the attack itself (for example, availability of attackers, best attacker of the team), as well as the block of the opposing team (for example, weaker blocker) (Papadimitriou et al., 2004).

In male high-level volleyball, the spaces used to perform the attack are increasing (Marcelino et al., 2014). Regardless of the previous action efficacy, high-level setters are able to achieve optimum sets from unappropriate preconditions (Papadimitriou et al., 2004, Palao et al., 2004, 2005). This results in the setters being able to diversify the attack of their teams, producing a high variability of the setting action (Marcelino et al., 2012). This variability causes the teams to be less predictable in attack (Marcelino et al., 2014), destabilizing the opposing block (Afonso et al., 2005a; Mesquita and Graça, 2002). This can be one of the reasons for our results, since in the case of non-zone four sets, the uncertainty in the opponent blockers increases, not allowing them to appropriate block the zone.

In relation to the tempo of the set, the results showed that this variable predicted the block participation, obtaining that when the setter performed first or second times, and not third times, it produced a decrease in the number of players to the block.

In line with our results, we found previous studies in which it was obtained that in fast sets, first and second times, double and triple locks were reduced, increasing situations in which the attacker was faced with single player blocks (Afonso et al. al., 2005a). 
The evolution of volleyball as sport has increased the attack speed, generating a mayor time deficit to blockers (Katsikadelli, 1995, 1996; Zimmerman, 1995, 1999). As Buscá and Febrer (2012) indicate, in a slow game, with attacks in third tempo, blockers will easily predict the attack zone. Therefore, the increase in the attack speed hinders the blockers performance. That is the reason why setters try to accelerate the attack phase. The increase on the speed of the attack phase could lead to a lower number of blockers (Afonso et al., 2005a; Afonso and Mesquita, 2011), being, the tempo of the attack, a relevant factor to destabilize the opposing team (Afonso et al., 2010).

In conclusion, setting variables as the setting zone, type of set, set's area and tempo of the set could affect to the block participation. This questions may be considered in training and competition, highlighting to in the receivers the need for excelent receptions, in order to allow jumping sets. Therefore, it would be interesting to considerate the relevance of an adequate decision-making of the setter in the setting action (type of set, set's area and tempo of the set), in order to reduce the block participation of the opposing team.

\section{AKNOWLEDGEMENTS}

This work has been funded by the University of Extremadura and group Banco Santander.

This work has been developed through the project funded by the Ministry of Science and Innovation entitled "MASVb System of competitive assessment and technical guidance for the Spanish Superleague Volleyball" (DEP2011-27503).

This study was made possible thanks to the contribution of the Consejería de Economía e Infraestructuras de la Junta de Extremadura (Spain) through the European Regional Development fund.

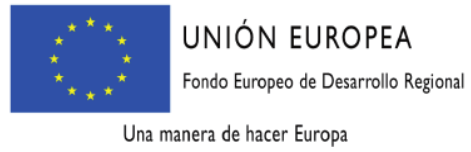

\section{JUNTA DE EXTREMADURA}

Consejería de Economía e Infraestructuras

\section{REFERENCES}

1. Afonso, J., Mesquita, I., \& Palao, J.M. (2005a). Relationship between the tempo and zone of spike and the number of blockers against the hitters. International Journal of Volleyball Research, 8(1), 1923.

2. Afonso, J., Mesquita, I., \& Palao J.M. (2005b). Relationship between the use of commit-block and the numbers of blockers and block effectiveness. Int J Perf Anal Spor, 5(2), 36-45.

3. Afonso, J., Mesquita, I., Marcelino, J., \& Silva, J. (2010). Analysis of the setter's tactical action in high-performance women's Volleyball. Kinesiology, 42(1), 82-89.

4. Araújo, R., Mesquita, I., \& Marcelino, R. (2009). Relationship between Block Constraints and set outcome in Elite Male Volleyball. Int J Perf Anal Spor, 9, 306-313.

5. Buscà, B., \& Febrer, J. (2012). Temporal fight between the middle blocker and the setter in high level volleyball. Rev int med cienc act fís deporte, 12(46), 313-327.

6. Castro, J., \& Mesquita, I. (2008). Estudo das implicações do espaço ofensivo nas características do ataque no voleibol masculino de elite. Revista Portuguesa de Ciências do Desporto, 8(1), 114-125. https://doi.org/10.5628/rpcd.08.01.114 
7. Castro, J.M., \& Mesquita, I. (2010). Estudo das implicações do espaço ofensivo nas características do ataque no Voleibol masculino de elite. Revista Portuguesa de Ciencias do Desporto, 8(1), 114125.

8. Fröhner, B., \& Zimmermann, B. (1996). Selected aspects of the developments of men's volleyball. The Coach, 4, 14-24.

9. Joao, P.V., Leite, N., Mesquita, I., \& Sampaio, J. (2010). Sex Differences in Discriminative Power of Volleyball Game-related Statistics. Percept Motor Skill, 111(3), 893-900. https://doi.org/10.2466/05.11.25.PMS.111.6.893-900

10. Katsikadelli, A. (1995). Tactical analysis of the attack serve in high level volleyball. J Hum Movement Stud, 29, 219-228.

11. Katsikadelli, A. (1996). A comparative study of the attack serve in high level volleyball tournaments. J Hum Movement Stud, 30, 259-267.

12. Lobietti, R. (2009). A review of blocking in volleyball: from the notational analysis to biomechanics. Journal of Human Sport and Exercise, 4(2), 93-99. https://doi.org/10.4100/hhse.2009.42.03

13. Marcelino, R., Afonso, J., Moraes, J.C., \& Mesquita, I. (2014). Determinants of attack players in highlevel men's volleyball. Kinesiology, 46(2), 234-241.

14. Marcelino, R., Sampaio, J., \& Mesquita, I. (2012). Attack and serve performances according to the match period and quality of opposition in elite volleyball matches. J Strength Cond Res, 26(12), 33853391. https://doi.org/10.1519/JSC.0b013e3182474269

15. Matias, Cristino Julio Alves da Silva, \& Greco, Pablo Juan. (2011). Análise da organização ofensiva dos levantadores campeões da superliga de voleibol. Revista Brasileira de Ciências do Esporte, 33(4), 1007-1028. https://dx.doi.org/10.1590/S0101-32892011000400014

16. Mesquita, I., \& Graça, A. (2002). Probing the strategic knowledge of an elite volleyball setter: a case study. International Journal of Volleyball Research, 5, 6-12.

17. Mesquita, I., Guerra, I., \& Araújo, V. (2002). O processo de formação do jovem jogador de voleibol. Lisboa: CEFD.

18. Mesquita, I., \& César, B., (2007). Characterisation of the opposite player's attack from the opposition blocks characteristics. An applied study in the Athens Olympic games in female volleyball teams. Int J Perf Anal Spor, 7(2), 13-27.

19. Morante (2014). VA-Sports [Voleibol]. Software de Análisis Observacional aplicado al Voleibol. Desarrollo de Software Deportivo, S.L. León.

20. Moreno, M.P., Moreno, A., Ure-a, A., Iglesias, D. y Del Villar, F. (2008). Application of mentoring through reflection in female setters of the Spanish National Volleyball Team: a case study. Int J Sport Psychol, 39(1), 59-76.

21. O'Donoghue, P., \& Holmes, L. (2015). Data Analysis in Sport. London: Routledge.

22. Palao, J.M., Santos, J.A., \& Ure-a, A. (2004). Effect of the setter's position on block in volleyball. International Journal of Volleyball Research, 7(1), 29-32.

23. Palao, J.M., Santos, J.A., \& Ure-a, A. (2005). Effect of setter's position on the spike in volleyball. J Hum Movement Stud, 48(1), 25-40.

24. Palao, J.M., \& Martínez, S. (2013). Utilización de la colocación en salto en función del nivel de competición en voleibol masculino. Revista Euroamericana de Ciencias del Deporte, 2(1), 43-49.

25. Papadimitriou, K., Pashali, E., Sermaki, I., Mellas, S., \& Papas, M. (2004). The effect of the opponents' serve on the offensive actions of Greek setters in volleyball games. Int J Perf Anal Spor, 4(1), 23-33.

26. Selinger, A., \& Ackermann-Blount, J. (1986). Arie Selinger's power volleyball. St. Martín Press: New York. 
27. Tsivika, M., \& Papadopoulou, S. (2008), Evaluation of the Technical and Tactical Offensive Elements of the Men's European Volleyball Championship. PhysicalTraining, 2.

28. Valladares, N., García-Tormo, V., \& Joao, P.V. (2016). Analysis of variables affecting performance in senior female volleyball World Championship 2014. Int J Perf Anal Spor, 16, 401-411.

29. Valadés, D., Palao, J.M., Aúnsolo, A., \& Ure-a, A. (2016). Correlation Between Ball Speed Of The Spike And The Strength Condition Of A Professional Women's Volleyball Team During The Season. Kinesiology, 48(1), 87-94.

30. Zimmerman, B. (1995). Selected aspects of the development of men's volleyball. 1994 men's world championship in Greece. International Volley Tech, 1, 411.

31. Zimmermann, B. (1999). Changes and possibilities with the introduction of libero in men's world class volleyball. The Coach. 1, 21. 